\title{
Reality Turned Magical: A Comparative Reading in No Other Life by Brian Moore and Over the Bridge by Mohamed El-Bisatie
}

\author{
Usama Nabih Raslan \\ Associate Professor, Department of English, Faculty of Archaeology and \\ Languages, \\ Matrouh University, Egypt \\ osamaraslan@mau.edu.eg
}

\begin{abstract}
The main purpose of this paper is to conduct a brief comparative study of contemporary Irish and Egyptian fiction from the perspective of magical realism: No Other Life (1993) and Over the Bridge (2006), selected from Brian Moore (1921-1999), an Irish-Canadian screenwriter and novelist, and Mohamed ElBisatie (1933-2012), an Egyptian short storyteller and novelist. Although these two novels are the aesthetic outcome of two completely different Western Eastern cultural milieus, they seem to share one interesting literary feature in common. The study contends that their authors adopt a marvelous literary genre as a narrative medium only to convert whatever is real into something imaginary. While Moore employs his dreamy landscape of Ganae to reflect upon the painful histories of Haiti, not Ganae, El-Bisatie utilizes the idealistic city of al-Khaldia to divulge the oppression exercised over Egypt, not al-Khaldia. To accomplish such an artistic objective, each novelist resorts to different magical-realist techniques. Such technical devices enable both of them to set up a graphic illustration of reality that represents factual happenings in terms of magical occurrences. This critical achievement led one to infer that the two pieces under study offer a seditious agenda that resists despotism and governmental ineptness whenever they exist.
\end{abstract}

Keywords: No Other Life; Over the Bridge; Brian Moore; Mohamed El-Bisatie; Magical Realism

\section{Introduction}

The aim of the present research paper is to examine magical realism in Brian Moore's No Other Life (1993) and Mohamed El-Bisatie's Over the Bridge (2006) from a comparative perspective. Although Moore (1921-1999), an Irish-Canadian 
screenwriter and novelist, and El-Bisatie (1933-2012), an Egyptian short storyteller and novelist, belong to two completely different cultural backgrounds, they both tend to use magical realism as a technical device in order to manipulate real political issues. The two novels under study will, thus, be analyzed in the light of the magical-realist theory to show that the magical aspect of reality is employed aesthetically to unfold the bitterness caused by the socio-political circumstances.

Magical realism is a popular mode of "literary and artistic expression" (Erickson, 2005, p. 247) that offers "magical happenings in a realist matter-of-fact narrative" (Bowers, 2004, p. 2). This definition signifies that magical realism is an oxymoronic term, mainly because it includes "a binary opposition" (Slemon, 2003, p. 409) between the magical and the real, two contradictory forces, each of which aiming at creating "a different kind of fictional world from the other" (Slemon, 2003, p. 409). The intertwining of the codes of realism along with those of the magical provides both Moore and El-Bisatie with an aesthetic power by means of which reality is turned into appearance, or rather imagination. In his speech upon being awarded the Nobel Prize for literature, the Colombian novelist, Gabriel Márquez (1988), noted that such a power might help the artist achieve an "outsized reality" (p. 89). Neither does this reality depict a traditional concept of the conditions of humanity, nor does it reflect human existence as it really is. Rather, it is a new literary medium that reveals the suffering and setbacks of humanity, mainly because it flows from the inner world of the artist.

In order to hammer home this vision, the novelist should be guided by what Márquez calls an "insatiable creativity" (p. 89), an artistic talent that helps him/her combine seamlessly the real with the imaginary. Such a combination may probably produce a portrait of reality, replete with the "sorrow and beauty" (p. 89) of the present. Not only does this "outsized reality" depend on the writer's individual talent, but it also draws on the rational explanation of the reasons behind the downfall of the community. That is why Márquez calls upon writers to compose an aesthetic mélange out of their "unbridled reality" and "imagination" (p. 89), so that they may fictionalize "the ravages of life" (p. 89). Viewed in this light, the literary theory may demand a new realistic vision, an artistic approach that reconciles the real and the imaginary, with the purpose of making the magical occurrences of "our lives believable" (p. 89). This, in simple terms, is magical realism. 


\section{Rationale and Scope of the Study}

The main purpose of the current paper is not only to draw a comparison between Moore's No Other Life and El-Bisatie's Over the Bridge, but also to highlight how the element of magical realism exposes the socio-political dimension by mixing the real with the magical. Though Moore and El-Bisatie's literary output are the outcome of two completely diverse cultural climates, both novelists openly voice their own similar talents as realist artists. However, a close reading of their two novels insinuates one to infer that both writers seem to be innovative magicalrealist artists. They both lay heavy emphasis on their insatiable creativity with a view to composing a narrative discourse, which may deploy magical-realist strategies in the hope of creating a fictional leitmotif, or rather a magical-realist world, a narrative practice that transposes the real, changing it into an imaginative icon.

Since magical realism is an artistic mode of realism that effaces the fake boundaries between the real and the imaginary, the study addresses several research questions: 1) What are the aesthetic features of magical realism? 2) How is the real turned magical in No Other Life and Over the Bridge? 3) What are the magical-realist motifs created and strategies adopted by both writers? 4) What are the aspects of similarity and dissimilarity between the two novels under study?

\section{Moore's No Other Life}

Although Moore's No Other Life and El-Bisatie's Over the Bridge are the outcome of two completely diverse cultural climates, they tend to display a creative talent for criticizing absolute political systems. A close reading of both novels urges one to infer that their authors seem to lay heavy emphasis on their insatiable creativity with a view to achieving what Márquez calls outsized reality. To achieve such a reality, Moore contends that he is "a truthful writer" (2021, para. 9). Rather than experience the usual events as they are, he provides "totally unreal" (2021, para. 5) narrative situations which propel the readers to really believe the authentic dimension of the unbelievable aspect of the narration.

In order to accomplish such an unreal narrative vision, Moore sets his No Other Life in a fictional landscape, in the imaginary Caribbean island of Ganae, where the narrative raises many social and political issues regarding the history of Haiti. The novel, thus, employs "the first-person narrative" (Gearon, 1998, p. 39) 
of Paul Michel, a French-Canadian Catholic priest, who looks back in time to tell the story of Jean-Paul Cantave, the hero of the novel known later as Jeannot. Michel saves the young Jeannot from a miserable life of oppression and poverty to enable him to join the "elite secondary school" (Gates, 1993, p. 22) in the capital of the island with the ultimate purpose of preparing him for the priesthood. However, instead of becoming a priest, Jeannot opts for political power by winning the election, thus becoming the president of this fictitious land. In his attempt to build up a democratic system in such a destitute nation, he faces political challenges, where he attacks the supporters of the old regime particularly represented by Doumergue. His revolutionary agenda forces the Catholic Church and the army headed by General Macandal to coup against him. Rather than surrender submissively to the coup, Jeannot asks the people to gather outside the churches to pray for Ganae where he disappears in a mythic way, leaving "those around him" (Hicks, 2007, p. 151) no options but to wait for his return to lead an armed revolt.

\section{El-Bisatie's Over the Bridge}

Similarly, El-Bisatie holds that he is a realist novelist. His realistic vision, like Moore's, tends to reflect the unreal aspect of reality in terms of his vivid imagination. In an interview with al-Jarida Journal, El-Bisatie argues that he innovates a new realistic approach via which the fake limits between reality and imagination are effaced. His critical view drives one to figure out that El-Bisatie's realistic vision, like Moore's, carries one to the heart of Márquez's outsized reality, mainly because it shows that the writers ought to "register truthfully the sociopolitical setbacks in terms of their individual talent: they are not social reformers. They should utilize their boundless imagination to delve too deeply into such dilemmas to depict the leading cause behind them, not to find a possible solution for them" 1 (2010, para. 3 [trans. mine]).

In order to accomplish such a vision, El-Bisatie's Over the Bridge, like Moore's piece, is set in the fictitious city of al-Khaldia in Upper Egypt. This imaginary setting helps El-Bisatie to employ the third-person omniscient narrator to set forth the story of Salem, a penniless auditor at the Ministry of Interior. This person resorts to his own bureaucratic experience and "vivid imagination to forge documents that legalize the existence of the nonexistent city of al-Khaldia and its police station" ${ }^{2}$ (El-Bisatie, 2005, p. 8 [trans. mine]). Such an action provides Salem, the hero of the narrative, with a chance to draw off the monthly payroll 
and rewards of such imaginary police department. To accomplish his plan, he depends on Younis, a restless poor officer, to act out the role of the financial deputy of al-Khaldia's police station in return for a monthly salary. Later, Salem gets a slab of thin plywood and modeling clay to imagine the topography of the city including the strict social stratifications between those who have/dominators and have-nots/dominated. He divides al-Khaldia into two districts, the new and the old. The former stands for the wealthy new section with its luxurious atmosphere of villas and swimming pools, the latter refers to the miserable people of the old quarter. To complete the portrait of the fictional city, Salem adds a Nile bridge to connect the two incompatible parts of al-Khaldia. El-Bisatie employs such a fictional landscape to address heavy criticism at the ineptness and injustice of the Egyptian government, represented by the city's chief of police.

\section{Magical Realism: Theory and Practice}

It is important to revert momentarily to magical realism before applying its artistic achievement - the representation of the real in terms of the magical - to No Other Life and Over the Bridge. In their "Introduction: Daiquiri Birds and Flaubertian Parrot(ie)s" (2003), Lois Zamora and Wendy Faris outline the building blocks of magical realism. They argue that such a school "is a mode suited to exploring and transgressing boundaries" (p. 5) between the real and imaginary. That is why the fictional world composed by magical realism stamps out the static boundaries standing between "the historical and the imaginary" (p. 5) as well as the antithetical distinctions separating ontological, not political, and geographical elements from the domain of the imaginary. By dissolving such disjunctions, magical realism is conceived to be a reconciliatory narrative medium. That is why magical realism is but "an extension of realism" (p. 5), mainly because it does not ignore the ethics of literary realism. Rather, it establishes an aesthetic mélange of the real and imaginary ulterior motives that bring on socio-political corruption. However, its central agenda relies greatly on resisting the rational analysis of realism with a view to contending a new theory of artistic reality. By so doing, the magical-realist artist intends to consider the "liminal territory between or among" (p. 6) the magical and the real so as to refashion a new realistic vision that obliterates the false divisions between the real/historical and the imaginary/magical.

Establishing a close rapport with the real/historical, magical realism brings out a marvelous political narrative discourse. This endows magical-realist writers with a critical practice to scrutinize "totalitarian regimes" (Bowers, 2004, p. 4). In 
its very essence, magical realism resists fundamentalism and totalitarianism, not to say defies "racism, ethnicity and the quest for tap roots, origins, and homogeneity" (Cooper, 1998, p. 22). The attack on totalitarian structures highlights two critical icons, regarding the aesthetic achievement of magical realism. First, it sustains the political thread of magical realism; second, it shows that all magical-realist authors are subversives. Zamora and Faris find that the seditious aspect of such discourse does not only wipe out the counterfeit boundaries between the real and the imaginary, but also instigates a new realistic vision marked by "in-betweenness" and "all-at-onceness" space. To enrich such a vision, the magical-realist novels should be packed with "hallucinatory scenes and events, fantastic/phantasmagoric characters." In employing fantastic events and characters, the magical-realist artist can easily fictionalize the "recent political and cultural perversions." The depiction of such perversions forces the artist to represent historical events in terms of magical happenings with a view to criticizing the dominant authority that subdues the existing structures of power:

Magical-realist texts are subversive: their in-betweenness, their allat-onceness encourages resistance to monologic political and cultural structures, a feature that has made the mode particularly useful to writers in postcolonial cultures and, increasingly, to women. Hallucinatory scenes and events, fantastic/phantasmagoric characters are used in several of the magical-realist works discussed here to indict recent political and cultural perversions. (p. 6)

The subversive aspect of magical realism implies that magical-realist artists tend to mix the magical with the real in the hope that they may depict the heterogeneous aspects of reality: "seen and unseen, visible and invisible, rational and mysterious" (Cooper, 1998, p. 32). The aesthetic representation of such aspects entices one to conclude that magical-realist works are resonant with historical codes, which have twofold functions: first, they help the critics to situate the pieces in "a particular context" (Bower 73); second, they carry the readers into the heart of "already existing historical assumptions" (Bower 73). In her book, Ordinary Enchantments: Magical Realism and the Remystification of Narrative (2004), Wendy Faris, the professor of comparative literature at Texas University, examines the key features of the authentic political vision produced by magical realism. Her examination contends that magical realism is but an aesthetic theory that mixes realism with the fantastic so that the magical grows "organically within 
the ordinary" (p. 1). In fictionalizing the ordinary/real in terms of the magical/imaginary magical realism achieves an artistic portrait of reality to "describe an impossible event," (p. 90) which interprets the present by devastating the artificial distinctions between the real and the magical. In order to blur such fake boundaries, Faris spells out that any magical-realist piece should be replete with five main criteria: a. irreducible element, b. presence of the phenomenal world, c. unsettling doubts, d. merging different realms, and e. disturbing received ideas about time, space, and identity:

First, the text contains an "irreducible element" of magic; second, the descriptions in magical realism detail a strong presence of the phenomenal world; third, the reader may experience some unsettling doubts in the effort to reconcile two contradictory understandings of events; fourth, the narrative merges different realms; and, finally, magical realism disturbs received ideas about time, space, and identity. (p. 7)

Faris' critical practices motivate one to infer that magical realism engenders a narrative practice that empowers the resistance against absolute political powers. Motivated by such a space, Moore and El-Bisatie tend to employ magical realism as a narrative framework, to criticize the dominant authority that subdues the existing structure of power.

\section{Discussion:}

\section{No Other Life: How Reality is Turned into Magical}

In No Other Life, Moore relies on a magical-realist technique through the invention of the fictional landscape of Ganae. Not only does Ganae change the constant ideas about time and space, but it also, to borrow Cooper's words, brings into prominence "a third kind of space" (1998, p. 33), a space that cannot be discovered on any map. The ultimate outcome of Moore's boundless fantastic imagination, Ganae becomes an aesthetic icon in itself. In the meantime, it can be taken as a liminal territory created by Moore to reflect the socio-political conditions of Haiti, following the investiture of Father Jean-Bertrand Aristide (1953), the first elected president of Haiti, who rose to power in 1999. In so doing, Moore alters the course of the past and enshrouds its truth in order to originate "new ways to interpret marginalized viewpoints" (Hicks, 2007, p. 137) regarding the citizens of Ganae. 
The plot of No Other Life centers around the character of Michel, a white catholic priest, who watches a videotape made for celebrating his formal retirement. This farewell ceremony makes him remember Jeannot, the hero of the narrative, whose absence instills in Michel's mind a strong belief that he is a clergyman with a deep secret, a tragic story never told before. Thus motivated, Michel gradually recalls the first moments at which he met orphan and famished Jeannot at Toumalie, a deserted village which was packed with ignorance, backwardness, frustration, and starvation. He also envisages the tragedy that befell Jeannot as a person and all the Ganaeans. As a result, the moments his feet dragged on the ground of Ganae, Michel is deeply frustrated because of the state of wretchedness suffered by the Ganaeans. Ganae is presented as an exotic island in the Caribbean, "but is as poor as any African country" (Moore, p. 4); most of its population is illiterate and the type of education provided by the government is extremely inefficient. Although the college of St Jean in which Michel works is the only qualified institution in the capital of Ganae, it is established on a severe social stratification that accepts solely "the mulatto elite" (Moore, p. 5), not the poor. The mulattos are the rulers of Ganae: they compose the majority of the parliament and have strong political ties with the United States of America. They are completely isolated from the poor in "large estates behind high walls and security gates" (Moore, p. 5) guarded by "black servants" (Moore, p. 5). Even though Ganae is "a black republic" (Moore, p. 5) in which the noir is supposed to be the rulers, the mulattos are the actual political leaders of the nation.

The horrific gloomy conditions of Ganae urge Michel to treat Jeannot in terms of "the father/son relationship" (Hicks, 2007, p. 147). As a surrogate father, Michel supports Jeannot until he receives his doctorate in French literature in France, becoming thus eligible for the presidency of the island. Upon his return from France, Jeannot becomes "an ordained priest" in Ganae where he tries to employ religion to serve his political project. In his first sermon, he addresses the audience as if they were his siblings, contending that church is not merely "archbishops and popes" but a political sanctuary for the people. Here, the priest's job is to draw the attention of the Ganaeans to "the unholy" political practices that sell all the national products to foreign countries while depriving the native people of any profits. In order to implant the seeds of revolution in the Ganaeans, Jeannot asks them to follow "the path of Jesus" in terms of which the lord orders the slaves to protest against the makers of their oppression. Apart from removing the endless 
poverty that hangs over Ganae, Jeannot's alleged revolution paves the way for the dominated to dream of enjoying social existence justly:

We must speak out against those who exploit our poor.

We must take the path of love.

The path of love is the path of Jesus.

Help us climb out of this endless poverty.

We do not ask for riches.

We ask to live the lives of the poor

But not lives of starvation and despair,

Not the lives of slaves. (Moore, p. 28f)

Moore uses Jeannot's homily to transform the imaginative histories of Ganae into the real ones of Haiti - the hard times that preceded the overthrowing of François Duvalier (1907-1971), Haiti's despotic ruler. The invention of Ganae along with Jeannot's politico-religious discourse in which he supplicates for wiping out the Ganaeans' despair and starvation results in a "sensory data" (p. 45), to quote Faris (2004). This data implies that No Other Life is a magical-realist piece, mainly because it creates "a narrative space that we might call the ineffable in-between" (p. 45), an aesthetic space in which the magical events and characters of Ganae are fused into the historical realities of Haiti. In this respect, Moore employs Jeannot as a magical-realist persona with a view to novelizing the rise and decline of Aristide, as well as revealing the sociopolitical setbacks of Haiti, not Ganae.

The sermon referred to above instigates Jeannot's "movement from the world of religious ministry" (Gearon, 1998, p. 39) into the field of politics. His role forces the elite of Ganae to try to assassinate him twice while he is celebrating the Mass. Fortunately for him, they fail to perpetuate their plot. Instead of being horrified by the assassination attempts, he "did not flinch" (Moore, p. 33). He faces the assailants with a heavy heart resonant with faith, extending his arms bravely as if he receives the bullets/aggression warmly. His steadfast courageous situation leaves the marauders no options but to cease firing. Once again, they raise their rifles to shoot at Jeannot, but he neither feels gripped by fear nor obsessed with such strange happening that exceeds imagination. Baffled by this scene, the attackers flee from church: never believing in the reality of what has taken place. This magical-realist scene makes Jeannot rise to the position of prophets: 
Jeannot did not flinch. He stood facing the killers, his arms outstretched as if to embrace them. His face showed love, not fear. At this point the marauders in the body of the church ceased firing and, like the rest of us, stood staring up at Jeannot on the altar. The other assailants, buffeted by the panicky congregation, began to lay about them with rifle butts and machetes as they beat their way back to the church doors. . .. What was being said was that Jeannot ... was a prophet, people said. God had sent him to save Ganae. (Moore, pp. 21-22)

Jeannot ascends to the stature of prophets when the bullets deliberately miss him. This magical-realist schema, to cite Faris, is but an "irreducible element" (2004, p. 7) employed by Moore to transfer the real histories of Haiti into the imaginary Ganae. The fact that Jeannot survived the two assassination attempts is but an irreducible magical-realist element, in which Moore fictionalizes a mystery phenomenon that cannot be highlighted in terms of "the laws of the universe" (2004, p. 7), not of those of logic. He asserts that in terms of narration, "magical things 'really' do happen" (2004, p. 8) in relation to the real histories of Haiti, not Ganae. To better understand the magical-realist significance of such an irreducible element, one should consider the very Haitian history. Alex Dupuy (2007) argues that the Haitian government feels a bitter enmity towards the increasing popularity of Aristide's political sermons. This hostility instigates the government to seek to assassinate him for three times, but in vain. Surviving such attempts, Aristide, not to say Jeannot, "proved his prophetic quality to his followers" (p. 83).

The close affinity between the real/Aristide and the imaginary/Jeannot soars high when the latter rises to power. No sooner does he become the president than he challenges harsh political efforts. This situation crystallizes as he rejects the Ganaean parliament's recommendation of nominating a qualified prime minister. His rejection brings on a constitutional crisis in Ganae, and hence the Ganaean congress calls for an emergency meeting to discuss the matter. In it, Jeannot addresses the enemies of his political system and accuses them of being the foes of the Ganaeans and Jesus. Such opponents who plot against the democracy and stability of Ganae should be brought to justice, mainly because it is "the time of machete" (Moore, p. 155). Jeannot suggests that the parliament ought to adopt revolutionary acts so that it may release the oppressed from the bonds of their oppressors: the elite and army leaders who live on sucking the blood 
of Ganae. The accomplishment of social justice requires "a sword" — not to say shapeless parliamentary mock discussions. This is supposed to be the revolutionary weapon via which the poor will erase all aspects of social injustice. Jeannot warns the army against attacking the people because they are armed with swords and machetes that can certainly defeat heavy weapons such as tanks:

Already, it has begun.

The time of the machete.

What do I mean by that? ...

Justice must be done.

It has not yet been done. ...

Let us have justice. (Moore, pp. 155-156)

Jeannot's machete speech is a subversive discourse. In it, Jeannot mingles the everyday Ganaean sociopolitical problems, as raised in the parliament, with the spiritual divinity of the Heavens. This mélange helps him create a magicalrealist mode in which he, to quote Faris's words, acts the part of "a shaman" (2004, p. 75). Jeannot's shamanic performance enables him to professionally mix his political agenda with his religious discourse to construct "a persona and a discourse that imaginatively" (2004, p. 75) engenders a magical-realist space, where magical occurrences are turned into real historical Haitian incidents.

Reverting to such historical events is but an evidence that Jeannot's shamanic performance finds an echo in Aristide who tries to prevent the neoDuvalierists from voting against his cabinet in the Haitian chamber. Dupuy observes that Aristide holds a double-edged discourse in which he "often gave contradictory messages-sometimes to the same audiences" (2007, p. 102). Dupuy's observation can be taken a step further to corroborate the concept that Moore is truly a magical-realist innovative novelist. He creates the shamanic persona of Jeannot in order to show that both his shamanic performance and Aristide's speech are identical in that they attempt to satisfy the elite while simultaneously threatening them with the sword of God.

Jeannot's machete speech propels the Ganaean to "take to arms" (Gearon, 1998, p. 42) not only to root out the social and political oppression, but also to stop the spreading military coup. This coup appeared out when the parliament removes Jeannot upon his refusal to adopt democracy as a tool for governance. When arrested by the army, General Macandal, the leader of the military 
overthrow, offers Jeannot an opportunity to keep his position as a president on condition that he broadcasts a taped speech acknowledging the chamber's decree of appointing senator Raymond as the Prime Minister. Jeannot pretends to accept the offer, but changes the scheme, insisting that the speech should be live, not taped. Rather than declaring his total submission to the will of the Congress and the army, Jeannot calls upon the Ganaeans to gather outside the churches and meet him for reciting the Holy Rosary at the square of Notre Dame: "To pray to Our Father that He help ... end our troubles" (Moore, p. 216).

Jeannot's "rosary" seems to be a national anthem in which the marginalized Ganaeans repeat the words as if they were revolutionary slogans. This spiritual atmosphere makes Michel believe that Jeannot reaches the state of the "dying Christ" (Moore, p. 227) only to cry out at the audience of the rosary that he will dissolve into nothingness where nobody can find him. However, he will still haunt them in their dreams to keep reminding them that "the memory of the dead can bring about our freedom" (Moore, p. 226). Jeannot has an eternal political agenda that will never die. Rather, it should prevail because it lives within the hearts of the downtrodden, sustaining an unconquered power capable of setting the fire of revolution anew. Such an everlasting authority is but the path of God, which perpetuates the memory of the dead. This guarantees the achievement of democracy and freedom for the Ganaeans: "The dead are our leaders." The people of Ganae are no longer in need of imploring to Jesus since the revolutionary acts endow them with a holy place like that of the Christ: "they are the Messiah." Jeannot wipes out the fixed limits between the world of the dead and that of the living, through confirming that the elite exploit the living as well as the dead. No sooner does Jeannot finish the rosary than he vanishes by merging into nothingness, where nobody can find him:

The dead are our leaders.

You and only you

With the help of God

And the memory of the dead

Can bring about our freedom.

It will not happen in a day

Or in a year. ... It will happen when you

No longer ask for a Messiah. (Moore, pp. 226-27) 
Jeannot's rosary is not a traditional set of prayers. Rather, it is, to quote Faris, a representation of a "near-merging of two realms" (2004, p. 21), a mythical land in which Jeannot composes a strong connection between the world of the dead and that of the living. The oppression of the Ganaean masses produces a magical form of existence in which the elites dominate the dead and the living in a fictional landscape devoid of the Messiah. This magical-realist vision enables Moore to create "a double-sided mirror" (2004, p. 21) that combine the apparent occurrences of Ganae and the hidden realities of Haiti. Thus envisioned, the histories of Haiti become more magical than the marvelous realist aspect of No Other Life. The Jeannot of Ganae vanishes without a trace whereas Haiti's Aristide "makes his comeback" (Koy, 2015, p. 154) and is further elected as a president of Haiti after being removed by the rebellious people leading the coup.

Jeannot and Aristide are thus identical in three points. First, both are priests, who descend from a poor social background. Second, they become presidents and are then deposed by a military coup. Lastly, both employ religious discourse to strongly refute the injustice of archetypal dictatorships. Henry Gates (1993) points out that while Aristide stands "firm against the ruling class that remained in Haiti after the death of Papa Doc Duvalier" (p. 7), the absolute ruler of Haiti, Jeannot peacefully opposes Doumergue and the elite in the hope of supplying the marginalized of Ganae with a decent life. Unlike Aristide, who is initially forced to exile in the United States and then ultimately reelected as a president, Jeannot enjoys the solitude of nothingness. Fading away from the holy rosary becomes a magical-realist practice that makes Jeannot "a deity" (p. 7) in the eyes and minds of his followers.

By the end of the novel, Moore unravels the unsolved mystery of Jeannot's disappearance. An unknown woman drops into Michel's class at the college of St Jean, where she gives him "a pocket watch" that contains the initials J. P. C standing for Jean-Paul Cantave-Jeannot's stage name. Questioning the woman about the identity of the person who offered the watch as a gift, she tells him that it was Frederic of Toumalie, Jeannot's cousin. When Michel arrives at the village to investigate the matter further, he is baffled to discover that Jeannot died of a severe fever the previous winter. Surprised at Jeannot's tragic fate, Michel asks Fredric to guide him to the secret grave where Jeannot is buried. There Michel kneels sadly and weeps bitterly for the loss of such a legendary hero, whom the Ganaean believed to be the Messiah: "Jeannot who had passed into legend. If only 
he were the Messiah, if only the gravestone could be rolled back." Nevertheless, this time, this Jesus will never rise from the dead, because he lies now in peace in a world where "there is no other life":

And then I was alone with Jeannot, alone for the last time. I looked at the ground, anonymous as the unmarked graves of peasants who had died a hundred years ago. Jeannot, his incantatory voice forever silent, Jeannot who had passed into legend. If only he were the Messiah, if only the gravestone could be rolled back . . . I touched the muddied earth in a useless caress as though, somehow, he would know that I had come here. I wept but my tears could not help him. There is no other life. (Moore, pp. 240-241)

Commenting on Michel's prayers and grief portrayed at Jeannot's gravestone, one can infer that such acts, to use Faris's terms, are but "some shamanistic curing ceremonies" (2004, p. 105). Such ceremonies refer one to a magical-realist zone, presumably because they corroborate that Michael is a shaman who aims at breathing life into the dead bones of Jeannot. Not only does this magical-realist mode combine "the worlds of the living and the dead" (2004, p. 105), but it also blends fictional fiction with "non-fiction fiction" (Shepherd, 1994, p. 167) via No Other Life. In the novel, Moore adopts magical-realist strategies that bring into prominence the aesthetic interaction between the fictional Ganae and nonfictional Haiti, ensnaring his readers in the circle of magic.

\section{Over the Bridge: How Reality is Turned into Magic}

If Moore's No Other Life rests on the interstitial space of Ganae, El-Bisatie's Over the Bridge depends on a hybrid space. Such a mixed space is represented by an idealistic city-al-Khaldia which sprang out of El-Bisatie's imagination. Its creation helped him produce a graphic illustration of reality, highlighting the magical events which expose the very realities of Egypt. By this, I mean the sociopolitical conditions of the Egyptians during the reign of President Hosni Mubarak (1928-2020) who rose to power following the assassination of Anwar al-Sadat (1918-1981), the third President of Egypt. Although most of the events of El-Bisatie's novel takes place in an imaginary city called al-Khaldia (in Upper Egypt), El-Bisatie contends that "the novel is not a fantasy. Rather, it is a realistic 
piece replete with the creative imagination of Salem, the hero of the narrative" ${ }^{3}(2005$, para. 3 [trans. mine]).

From the very beginning of the novel, the pivotal character Salem, a wretched auditor at the department of security, is obsessed with a burning desire to transform the image of al-Khaldia from a concept in his mind into an intelligible reality. No sooner does he reach the office, where he works, than he puts some sheets of paper into an envelope "bearing the department letterhead" (El-Bisatie, p. 4). That was the eagle stamp which he concealed when a new seal has arrived, along with a copy of an administrative decree containing the signature of the head of human resources. He uses such tools to imitate the exact signatures of the officers responsible for establishing al-Khaldia, including the Minister of Interior. Never can anybody cast doubt on the authenticity of the documents of such a station, simply because Salem is the head of auditing department, and hence is responsible for overseeing all the monetary affairs. However, if any controller inquiries about the memorandum of al-Khaldia, Salem pretends to visit the filing section to check on the existence of the nonexistent papers. He, thus, carries on with the process of creating the fictitious city of al-Khaldia with its police station; he even stamps the fake minister's decree adding the following "key phrase":

'Based on the relevant statutes, for the sake of effective work, and in keeping with the authority vested in us, we have hereby seen fit to establish a police station in the city of Khaldiya.' (El-Bisatie, p. 7)

The counterfeit ministerial decree helps Salem to draw off the payroll of alKhaldia police station, changing the imaginary station into a reality. He utilizes his fertile imagination to divide the nonexistent city into two parts: the old and the new. Since the latter is designed for the elite and the ruling class, it is marked by "modern architecture, its broad, straight streets, streetlights" and palaces surrounded by Gardens of Eden, and servants who spend their life in the service of their masters. Besides, the elite set up "four pontoons" to satisfy their id:

The new quarter on the other side of the river is inhabited by businessmen and big-time merchants, and people in positions of authority. Some flats for the red-light district. There isn't a town without one. Two flats. No, we'll make it three. And who uses them. ... The police station is . . located not far from the riverbank and facing the old quarter on the other side, it's in an 
old two-story villa painted in non-glossy white with a sign on the front that reads, "Khalidiya Police Station." (El-Bisatie, pp. 19-20)

Salem's description of the sumptuous features of al-Khaldia reinforces the magical-realist aspect of the narrative. His detailed account of the modern architecture, pontoons, mansions and villas along with the people, who occupy such places, creates a fictional world. Here, the sociopolitical conditions of Egypt are turned into the magical representation of al-Khaldia. This fictional world, to quote Wilson, is a marvelous icon in which the portrait of the new quarter of alKhaldia operates. It is as if it were a truthful representation of the "extratextual world and which, thus, constantly beg comparison to" (2003, p. 217) the fatal impact of the Open-Door Policy or Infitah, first experienced by the Egyptians during the Sadat regime. To fully grasp the relationship between al-Khaldia's luxurious part and the painful realities of Egypt, one should consider the socioeconomic structure that prevailed in Egypt/al-Khaldia prior to the outbreak of the 25 of January, 2011 revolution.

Johns Bradley (2010) reviews the gloomy consequences of the Infitah on the social fabric of Egypt. Such an Open-Door Policy, founded by Sadat and supported by Mubarak, was to open a Pandora's Box of social ills. "Openers engaged in import trade" (p. 45) and dirty business, thus causing trouble and problems. It also gave birth to a new social class, consisting of "indigenous millionaires" (p. 45), who spent their life each in Mercedes and silk-stocking villas, calling to mind al-Khaldia's mansions and palaces surrounded by rosebushes and jasmine. Like Moore's Ganae, which was dominated by the mulatto elite, al-Khaldia is controlled by a new exploitative social class of "openers" (p. 45), who ruthlessly abused the Egyptians, not to say the people of al-Khalidia.

The thematic structure of Over the Bridge comprises four underlying magical-realist motifs, which all confirm the danger that the city of al-Khaldia was to become a real police-state. There is first the Inspector's attempt to arrest Ibrahim al-Umari, a dead communist comrade, which reflects the unjust practices of policemen. The sheriff receives an order from the Headquarters to arrest alUmari, a native of al-Khaldia, for participating in the "hunger strikes" in Cairo. The strikers attacked malls and storefronts and destroyed anything in their way. 
The state of chaos propels the authorities to search for the main catalyst activist behind the strike-al-Umari. Followed by a crowd of people, the inspector led a large force that raided al-Umari's house at the old quarter of al-Khaldia. No sooner had a soldier knocked at the house door than al-Umari's father opens with heavy heart, wondering why the police besiege the whole area. Asked about the place of his son, he told the policemen that they could find him resting by "the big sycamore tree." The police moved quickly to the place described only to discover that al-Umari passed away ten years before. However, the federal security department was not convinced and insisted that the inspector ought to send them "a copy of the deceased's death certificate" in order that they might remove the name from the lists of the most wanted:

Search for al-Umari. Wanted for interrogation. A native of the town. There were hunger strikes in the capital that lasted three days and nights. Most of the city's businesses were vandalized and their storefronts shattered. Thousands of cars were vandalized in the streets, and things reached the point where the president of the country had a helicopter stationed on the roof of his palace so that he could flee at a moment's notice. (El-Bisatie, p. 38)

Like Moore's Ganae, al-Khaldia is a mythical land through which El-Bisatie makes an analogy between the world of the dead and that of the living. Although al-Umari died ten years before, the police insisted on chasing him. This emphasizes the arbitrariness and ineptness of the police-state whose oppressive practices motivate El-Bisatie to engineer a magical-realist zone of existence. The arrest order of al-Umari along with the hunger strikes become magical-realist echoes of the food riots that took place in Egypt back in 1977, when President Sadat was in power.

The second crucial magical-realist motif comprised by the thematic structure of Over the Bridge is the collusion with the drug traffickers. Rather than imprisoning hashish dealers, the decayed police-state cooperates with them to formulate counterfeit drug confiscations at al-Khaldia. This corruption is best illustrated when the chief of police prepares a force to find two kilograms of hashish hidden inside a tin box by a tree in a park. Once arriving there, the police surround a specific tree and ask the gardener to dig beside its trunk. Digging as asked, the gardener is terrified to find a box of hashish for which he is arrested 
and taken to the police station to be cross examined for possessing and hiding narcotics, upon the investigations assistant indictment. The strange thing is that the inspector strongly believes in the legality of such an illegal dirty game. To even give the whole business a legal form, he proceeds to compose four reports: the "documentation," "examination," "disposal," and the "rewards statement."

The documentation report reveals the date and name of the confiscation as well as the unnamed informant, who cooperates with the police until they confiscate the drug. The examination report concludes that "the contraband sequestered" is comprised of two kilograms of very strong hashish known as "alA'war [one-eyed man]." The committee's recommendation is that the contraband of hashish that values 32000 Egyptian pounds ought to be destroyed in terms of law. The disposal report, carrying out the instructions of the previous committee, confirms that the confiscated hashish ought to be burnt in the desert, away from populated areas. Finally, the rewards statement explains that half of the reward value should go for "the unnamed informant," while the rest is to be distributed among the employees of the Khalidia's police station according to their salary, task and rank:

First, the documentation report: On such-and-such a day in suchand-such a month, and based on a tip supplied by an unnamed informant known to us, two kilograms of hashish were found buried under a tree. ... And an examination report: It has become apparent ... that the contraband sequestered on such-and-such a date ... consists of two kilograms of premium quality hashish which is violent in its effects. The brand name of the aforementioned contraband is known as 'al-A'war,' or, 'Blind Man,'. . . and it is recommended that it be destroyed. (El-Bisatie, pp. 54-55)

Unlike Moore who uses Jeannot's sermons to bring out the ineffable inbetween space, El-Bisatie employs the four previous reports to create a magicalrealist sensory data. This reflects how the inspector depends on the power of law to bestow legality on the fake confiscated hashish. It further indicates that ElBisatie designs the magical landscape of al-Khaldia to portray governmental ineptness. Corruption reaches its climatic points not only when the sheriff orchestrates the discovery of the hashish, but also when he drafts the four official reports to legalize the hashish contraband. The sensory fake data will create in the 
reader's mind a magical-realist landscape, imbued with historical indications, confirming the oppression exercised by the police-state over the Egyptians/Khalidians. In an interview with a victim of such unjust practices, Bradley observes that the police authorities work in terms of "a quota system" (2010, p. 120) not lawful acts. They arrest people publicly but randomly to check whether they have drugs or any other illegal possessions. The officers would fabricate a crime for anyone to fulfil their quota and gain rewards: "They do this all the time" (2010, p. 120).

The third important magical-realist motif included in the thematic structure of Over the Bridge is the complicity of the police in the spread of immoral activities. This is represented in the relationship between the chief of police and Madame Najwa, an infamous forty-years-old charming woman. Instead of "arresting her for running a brothel, the inspector turns a blind eye to her indecent activities, inherent in seducing young poor girls to leave their families in order to be pimped to the elite of the rich and senior government officials" ${ }^{4}$ (Haikel, 2014, p. 63 [trans. mine]). Though the inspector knows the details of Najwa's illegal acts, he tries to protect her more than once. He saves her from being investigated about the absence of Nawal, a young girl from a famished small village near alKhaldia known as Kafr al-Shamamm, whom Najwa makes of her a professional prostitute. Frustrated by the disappearance of his sister, a fourteen-years-old boy visits Khaldiya police station in the hope of acquiring any information that might help him reach his sister. In the station, the officer on duty investigates the boy on the conditions of his sister's absence, promising that the police will certainly untangle the riddle of her disappearance. Because the little boy has no relatives in al-Khaldia, the officer recommends that it is better for him to spend the night in the jail cell.

Hardly does the boy go in the confinement room than the prisoners try to sodomize him. They stare at him in the darkness of the jail and stretch out their flexed legs to prevent him from finding a place to rest. The boy relentlessly uses his foot to find out a space where he can sit, but the criminals force him not to manage "a sitting position," nor to keep on "his jilbab." Upon realizing that they intend to rape him, the boy resists them fiercely, but in vain. The more the grips of the prisoners tighten around the boy's body, the more he screams hysterically for help in the hope of being rescued. As soon as the jail door is opened and the boy is released, he harks back to his home village, swearing to give up the idea of 
searching for his sister forever. The inspector does not feel any sense of remorse. Rather, he gains satisfaction whenever he narrates such a bleak story:

Then, within moments, a hand had been clapped over his mouth, while another hand lifted up the bottom of his jilbab. He struggled, but more than one hand paralyzed his movement, and he could feel hot breaths near his face. He saw someone coming from the other side and pulling down his trousers, his features indistinguishable in the darkness. He tried to break loose again, but the grips tightened around his body. (El-Bisatie, pp. 99-100)

Unlike Moore who creates a magical-realist landscape by focusing on the shamanic performance of Jeannot and Michel, El-Bisatie utilizes the illegal practices of the chief of police to highlight the oppression and dirty corruption that afflict the Egyptians/Khaldians. The sheriff's orchestrating and supervising over the rape attempt of the boy is not a haphazard tragic incident. It is an outsized reality that, to quote Wilson, helps El-Bisatie engender "a fenestral translucency" (2003, p. 220), a liminal territory that shows how the imaginary oppressive treatment of the poor in the old quarter of al-Khaldia is transformed into the realities of Egypt.

Bearing this in mind, one can figure out that the violations committed by the inspector of Khaldiya police station unfold the setback of the Egyptians under the soft police-state. During Mubarak's era, Egypt/al-Khaldia, to borrow Amin's words, becomes "a soft state" (2011, p. 8) that issues laws without enforcing them. While the nouveau riche and lawbreakers, like Najwa, are rather above the law, simply because their power protects them, the downtrodden, i.e. the boy of Kafr al-Shamamm, have no options but to submit to the power of authority even if they do not commit any mistakes. In Egypt/al-Khaldia everything is put up for sale to the extent that Saddam Hussein, the late Iraqi President, spells out that Mubarak/the Inspector is "like a pay phone. You deposit your money, and you get what you want in return" (qtd.in Bradley, 2010, p. 22).

The fourth and last significant magical-realist motif included in the thematic structure of Over the Bridge is the authority's scheming against the working class. Here, the Inspector stands by $\mathrm{Sa}$ ' $\mathrm{di}^{\mathrm{i}}$, owner of the textile factory, in order to suppress the workers' dream of a decent life. Immediately as he receives the news that the textile-factory workers plan for staging a strike, the Inspector 
summons strong soldiers from the Central Security Department. To crush the imminent strike, the Inspector advises Sa'di to meet the labors and pretend to listen to their complaints, while he thinks of how to frustrate their attempt. Sa'di refuses to meet the workers who are assailed on their way home and are held in police custody, being accused of holding a strike. Upon inspecting them, the inspector's assistant discovers a piece of paper in which they register their due demands. In it, they ask Sa'di to cancel the decision issued lately by the factory administration regarding their free medical treatment "of work-related injuries" (El-Bisatie, p. 135). The administration had previously decided that the cost of any medical care ought to have been afforded by the workers themselves unless it is subtracted from their monthly wages. Although the workers call for a just a rightful demand, a decent health service, the authorities believe that this request is but an undeserved luxury: "Sa'di is right to put a stop to this tomfoolery" (ElBisatie, p. 135).

Unlike Moore's magical landscape of Ganae in which the marginalized took to arms to resist corruption and dictatorship of the supporters of Doumergue, ElBisatie's downtrodden workers opt for a peaceful scheme. However, the policestate is keen on crushing any movement of reform. The labor's due demand of a qualified health service is not a luxurious request, but the investigation officer stands fiercely against it, undermining its merit. This along with the violence used in putting down the strike would help in breeding a graphic depiction of reality. Not only does this reflect upon the dingy state of Egypt under Mubarak, but it also gives rise to a magical-realist zone through the nonexistent city of al-Khaldia that concerns the relationship between the victim and victimizer.

El-Bisatie's innovative use of magical realism reaches its peak by the end of the novel: the inspector is suddenly visited by Salem in his dream. Falling asleep, he first dreams of a charming woman approaching him. She is the wife of a textile factory worker whom the sheriff had arrested for staging a strike. The more she comes closer to his bed, the more he is torn between his wakefulness and dreaming. The woman looks like a professional prostitute who has come to seduce the sheriff romantically throwing off her clothes to show a "pink slip" and "voluptuous bosom" (El-Bisatie, p. 141). She thus kindles his desire to make love to her, an act interrupted by a strange male voice. This happens to be that of Salem whom the inspector suddenly finds standing by his bed. Instantly, the inspector 
rises out of bed and chokes Salem to death in the climax of the dream. There the lights of al-Khaldia's model are vanishing as dawn broke:

He stands beside the bed and looks at the two of you. Disoriented and disheveled, you push her off you and ... lunge at him, grab his neck and fling him to the floor. You kneel on top of him with your hands around his neck. He struggles beneath you, but you bin him between your thighs. Meanwhile, you keep up the pressure on his neck until at last you feel his body grow limp. ... The lights on the model were out, and dawn was breaking over the horizon. (El-Bisatie, p. 142)

Just as the death of Jeannot has provided Moore with a magical-realist space in which Michel employs the ideology of shamanism, the strangulation of Salem helps El-Bisatie produce through his absurd ending "an experimental social narrative that shows how the aggression and oppression of bureaucratic authority in Egypt transform al-Khaldia into a labyrinth that demises its creator" 5 (Fadle, 2009, p. 124 [trans. mine]).

\section{Conclusion}

Having thus read both Moore's No Other Life and El-Bisatie's Over the Bridge in the light of magical realism, I would like to conclude five essential points regarding their narrative achievement. Firstly, magical realism is a new school of literary realism that dissolves the false disjunctions between the real and the imaginary by offering an aesthetic fictional space. This critical practice provides Moore and El-Bisatie with a liminal territory that enables them both to depict matter-of-fact realist motifs in terms of magical happenings. Magical realism is, hence, a seditious discourse, mainly because it yields a realistic approach in terms of which artists can easily utilize their fertile imagination to castigate totalitarian regimes for subduing and oppressing the downtrodden.

Secondly, though Moore and El-Bisatie are the spokespersons for two completely diverse cultural milieus, they both seem to pick up magical realism from whose features they draw their technical devices. However, they both achieve different artistic effects. The former transfers the real into the magical with a view to exploring the painful histories of Haiti, not Ganae, whereas the latter mixes both elements to highlight the oppression experienced by the people of Egypt, not al-Khaldia. Unlike Moore who relies on Michel, the first-person 
narrator, to tell the story of Jeannot from A to Z, El-Bisatie hinges on the thirdperson omniscient point of view to narrate the story of Salem. For all that, both narratives end with the death of their pivotal characters: Jeannot and Salem. While the former dies in peace, the latter is strangled to death by one of the imaginary characters.

Thirdly, the close reading to No Other Life and Over the Bridge may show that Moore and El-Bisatie, alike, employ similar magical-realist bridging techniques. Not only does such critical maneuver enable them to instigate a graphic illustration of reality, but it also helps them both to combine the real with the magical. The invention of the imaginary Ganae yields an interstitial space in which the magical happenings of this fairy island stand for the histories of Haiti. Similarly, El-Bisatie orchestrates the nonexistent city of al-Khaldia in order to produce a hybrid magical-realist landscape. Still, while Moore's Ganae is conceived to be the framework of the narrative from the beginning to the end, ElBisatie's al-Khaldia is not a natural-born phenomenon within the layers of the narrative. Instead, it is a hybrid space within which the novelist dramatizes the mechanism of amalgamating the painful realities of Egypt into the magical territory of al-Khaldia.

Fourthly, Jeannot's political sermons in which he demonstrates the revolutionary political task of the priest bring into prominence sensory data, or rather an ineffable in-between space. Neither is Jeannot depicted as an ordained priest nor as a political leader. Rather, he is represented as a prophet sent by God to help the Ganaeans overcome socio-political injustice. This is best illuminated through four magical-realist schemas: 1) Jeannot's political sermons, 2) machete speech, 3) survival of the two assassination attempts and 4) magical rosary. Not only do such magical-realist leitmotifs reinforce the relationship between the imaginary Jeannot and the real Aristide, but they also highlight the sociopolitical setbacks of Haiti, not Ganae. By showing the role of religion in resisting despotism and oppression, Moore fuses the historical records of Haiti into the magical Ganae, simply because the supporters of Duvalier try to assassinate Aristide/Jeannot thrice. Upon failing, they forced him into exile.

Unlike Moore's narrative, El-Bisatie's is devoid of any politico-religious agenda. Instead of using religion as a defense mechanism, he deploys four magical-realist schemas: a) the inspector's attempt to capture al-Umari; b) the fake 
hashish confiscation; c) the pursuit of the chief of police to protect Najwa; and d) the Inspector's insistence on crushing the workers' demonstration. These four schemas yield a magical-realist sensory space which strengthens the aesthetic relationship between the historical present of Egypt and the imaginative alKhaldia. It also vindicates that El-Bisatie tends to rely on magical realism in order to encapsulate the oppression of the police state, governmental ineptness and injustice that attack Egypt when Mubarak gave rise to the birth of the soft state.

Finally, Jeannot's enigmatic disappearance from the rosary and accidental death may create a double-sided mirror. In it, Moore combines the magical occurrences of Ganae and the hidden realities of Haiti with a view to initiating a magical-realist portrait of reality. His achievement results in transforming the magical elements into the harsh realities of Haiti, particularly the extreme poverty and oppression that befall the Haitians during the reign of Duvalier and the reasons behind the coup that removed Jeannot/Aristide, Haiti's first democratically elected president. Like Moore's Jeannot, El-Bisatie's Salem, the hero of the narrative and the designer of al-Khaldia, is strangled to death.

If the death of Jeannot seems to supply Moore with a double-sided mirror, the strangulation of Salem endows El-Bisatie with a magical-realist improbable element. In it, El-Bisatie utilizes the dream structure with the purpose of carrying the magical occurrences of the fictitious al-Khaldia into the harsh realities of Egypt. His artistic accomplishment stems from the creative power of magical realism via which he fictionalizes the corruption, injustice and oppression brought on by Mubarak's sociopolitical agenda. This catastrophic agenda motivates the Egyptians, not to say the Khaldians, to force him to step down during the 25 January Revolution. In this regard, No Other Life and Over the Bridge are not merely innovative magical-realist powerful novels, but subversive narratives that resist dictatorship and governmental ineptness wherever they coexist. This assessment urges one to infer that the future research into comparative literature should consider the aesthetic interaction between Irish and Egyptian fiction.

\section{Endnotes}

Translations from Arabic are all mine.

$$
\text { 1- التعبير عنها و التصديب الو اقع و هو ليس مصلحاً اجتماعياً، ودور المثقف ليس إيجاد حلول لمشاكل الناس بل }
$$


2- فبطل الرواية وظف خياله في خدمة جيبه الفارغ حتى يمتلئ، فقام بتزوير أوراق ومكاتبات رسمية لإنشاء قسم شرطة و همي في مدينته الو همية.

3- ويشير البساطي إلى أن الرواية تتناول حدثاً حقيقياً ولكن خبال بطل الرواية جعل البعض يطلق

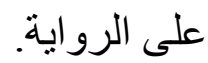

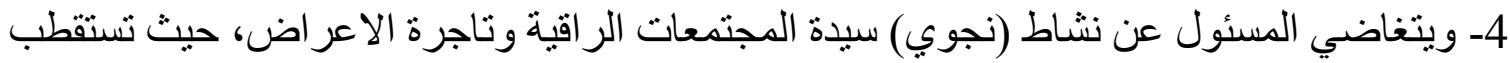

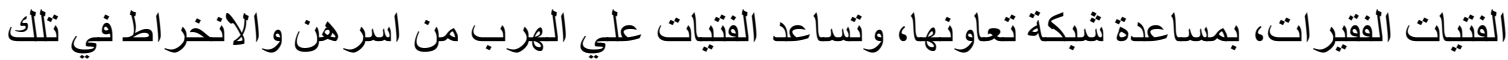

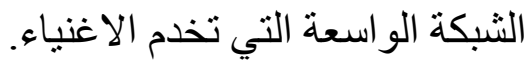

5- وييقي الر اوي المحيط بكل شيء علما يصف المشهد الاخير لدراما اجتماعية تجريبية، تشي بمدي تفاقم البيروقر اطية في المجتمع المصري، وتوحشها ـ ـ ـ في لعبة يمكن ان نطلق عليها الخالدية الددينة السلطة التي قتلت صاحبها.

\section{References:}

Amin, Galal. (2011). Egypt in the era of Hosni Mubarak: 1981-2010. The American University in Cairo Press.

Bowers, Maggie. (2004). Magic(al) realism. Routledge.

Bradley, Johns. (2010). Inside Egypt: The land of the Pharaohs on the brink of a revolution. Macmillan.

Brenda, Cooper. (1998). Magical realism in West African fiction: Seeing with a third eye. Routledge.

Dupuy, Alex. (2007). The prophet and power: Jean-Bertrand Aristide, the International Community, and Haiti. Littlefield.

El-Bisatie, Mohamed. (2005). Riwayati liayst fantasy wa al-Rif alami al-Mufadle [An Interview with El-Bisatie]. Magalt al-Jazira. Retrieved 22 July, 2020 from https://omferas.com/archives/374.

El-Bisatie, Mohamed. (2006). Over the bridge (Nancy Roberts, Trans.). The American University in Cairo Press. (Original work published 1993).

El-Bisatie, Mohamed. (2010). Inn Katabt sirati al-Zatiyah sayalanini ibnai [If I Write my cv, my Sons will Disregard me]. Al-Jaridah, May, 16. 
$\begin{array}{llll}\text { Retrieved } & 28 & \text { July, } & 2020\end{array}$

https://www.aljarida.com/articles/1461818124707013900/

Erickson, John. (2005). Magical realism and nomadic writing in the Maghreb. In Stephen Hart. and Wen-chin Ouyang, (Eds.), A companion to magical realism (pp 247-255). Tamesis.

Fadle, Salah. (2009). Al-Tamthil al-gamali ll-hyah fi ashrat riwayat arabiah:

Dirasah [Aesthetic Representation of Reality in Selected Arabic Novels]. Dar al-Adab.

Faris, Wendy. (2004). Ordinary enchantments: Magical realism and the remystification of narrative. Vanderbilt University Press.

Gates, Henry Louis. (1993). "The sword and the savior." New York Times Review of Books 12 sept, p. 7.

Gearon, Liam. (1998). No Other Life: death and Catholicism in the Novels of Brian Moore." Journal of Beliefs and Values, 19:1, 33-46, DOI: 10.1080/1361767980190103

Haikel, Abd-al-Azim. (2014). Taqnyat al-Fan al-Riwai anda Muhammad ElBisatie [The Art of Novel in El-Bisatie]. MA Thesis, Cairo University.

Hicks, Patrick. (2007). Brian Moore and the meaning of the past: An Irish novelist re-imagines history. Edwin Mellen.

Koy, Christopher. (2015). Representations of the Québécois in Brian Moore's novels. In Considering Identity: Views on Canadian Literature and History. 141-156. Retrieved January 5, 2020 from https://www.researchgate.net/publication/315478043_Representations _of_the_Quebecois_in_Brian_Moore's_Novels

Márquez, Gabriel. (1988). The solitude of Latin America: Nobel lecture, 1982. In Julio Ortega (Ed.), Gabriel Garcia Marquez and the Powers of Fiction (pp. 87-92). University of Texas

Moore, Brian. (2011). No Other Life. Bloomsbury. 
Moore, Brian. (2021). Brian Moore: My real strength is that I am a truthful writer. The Irish Times, Mon, Sep 6, np. Retrieved September 7, 2021 from https://www.irishtimes.com/culture/books/brian-moore-my-realstrength-is-that-i-am-a-truthful-writer- 1.3726350

Shepherd, Allen. (1994). "The Perfect role of the outsider: Brian Moore's no other life." New England Review (1990), Vol. 16, No. 3 (Summer) (pp. 164167). Retrieved March 11, 2020 from https://www.jstor.org/stable/40242898

Slemon, Stephen. (2003). Magic realism as postcolonial discourse. In Lois Parkinson Zamora and Wendy Faris, (Eds.), Magical realism: Theory, history, community (pp. 407-26). Duke University Press.

Wilson, Robert. (2003). The metamorphoses of space: magic realism. In Lois Parkinson Zamora and Wendy Faris, (Eds.), Magical realism: Theory, history, community (pp. 209-233). Duke University Press.

Zamora, Lois, and Wendy Faris, (Eds.). (2003). "Introduction: Daiquiri and Flaubertian Parrot(ie)s birds." In Magical realism: Theory, history, community (pp. 1-11). Duke University Press. 
الواقع سحر اً : قراءة مقارنة في روايتي "ليست ثمة حياة أخري" و "الخالديّة" لأديبين برايان مور و محمّد البساطيّ

$$
\text { د/ اسامة نبيه رسلان }
$$

قسم اللغة الانجليزية ـ كلية الاثار و اللغاتـ جامعة مطروح لبدان

\section{osamaraslan@mau.edu.eg}

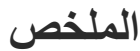

يقدّم هذا البحث قر اءة نقديّة مقارنة بين الأدب الأيرلنديّ متمثّلاً في رواية "ليست ثمة حياة أخري" (1993)

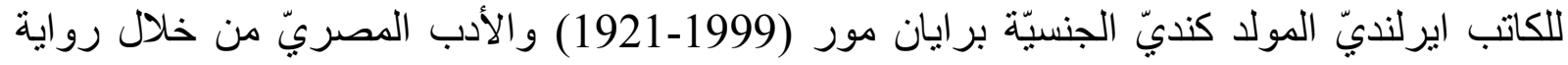

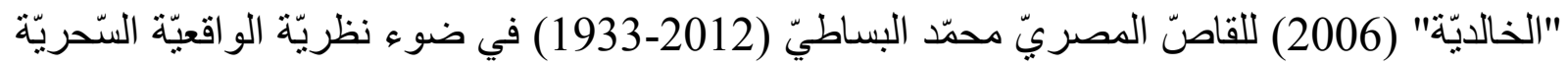
(Magical Realism)

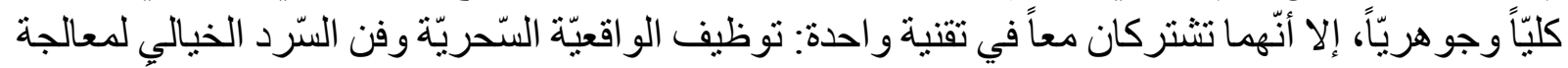

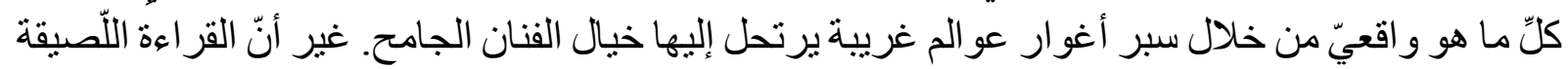

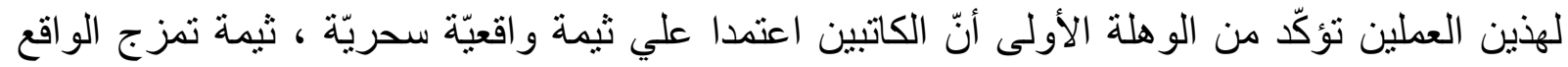

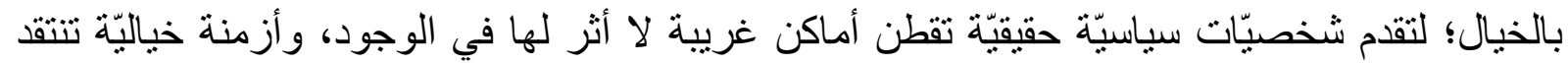

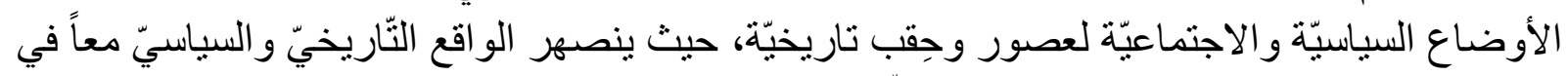

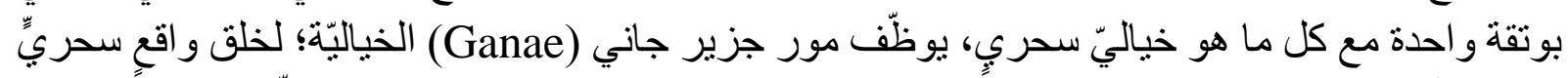

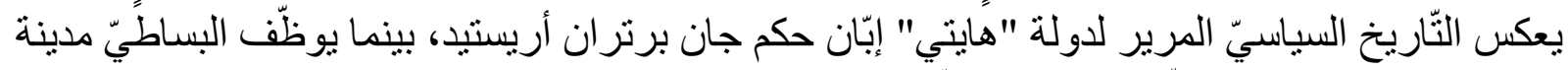

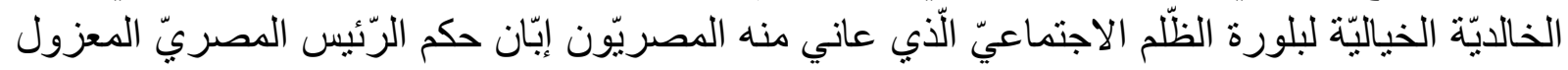

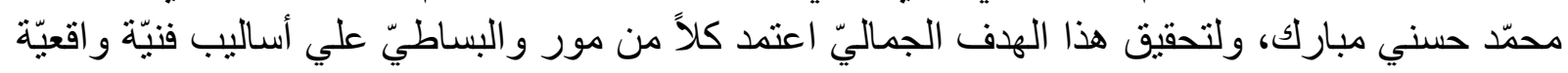
سحريّة؛ لرسم صورة جر افيّة تؤكّد أنّ كلا النّصّين يحملان أجندة ثوريّة تحارب الفيّة الفساد و الاستبداد أينما كانا.

الكلمات اللّّالةه: ليست ثمة حياة أخري، الخالديّة، براين مور، محمّد البساطيّ، الو اقعيّة السّحريّة 